\title{
PROTOPLAST FORMATION AND REGENERATION FROM STREPTOMYCES CLAVULIGERUS NRRL 3585 AND CLAVULANIC ACID PRODUCTION
}

\author{
Maria das Graças Carneiro-da-Cunha ${ }^{1}$; José Luiz de Lima Filho후 ; Galba Maria de Campos-Takaki* \\ ${ }^{1}$ Departamento de Bioquímica, Laboratório de Imunopatologia Keizo Asami, Universidade Federal de Pernambuco, Recife, PE, \\ Brasil; ${ }^{2}$ Núcleo de Pesquisas em Ciências Ambientais, Departamento de Química, Universidade Católica de Pernambuco, \\ Recife, PE, Brasil
}

Submitted: June 25, 2001; Returned to authors for corrections: August 20, 2001; Approved: November 28, 2002

\begin{abstract}
Protoplasts of the wild type Streptomyces clavuligerus NRRL 3585 (ATCC 27064) were formed from spores cultures obtained in the lag, exponential and stationary growth phases by using $0.5 \%$ glycine in the culture medium. The protoplasts were obtained by treatment of the cells with lysozyme (EC-3.2.1.17) 40,000 U (1mg/ $\mathrm{mL}$ ), in an osmotic solution for $90 \mathrm{~min}$ at $28^{\circ} \mathrm{C}$. The frequency of regenerated protoplasts in the lag phase was $1.7 \times 10^{3} \mathrm{CFU} / \mathrm{mL}\left(28.97 \%\right.$ ), in the beginning of the exponential phase $0.4 \times 10^{2} \mathrm{CFU} / \mathrm{mL}(31.67 \%)$, in the exponential growth phase $2.5 \times 10^{3} \mathrm{CFU} / \mathrm{mL}$ (46.30\%) and $1.0 \times 10^{5} \mathrm{CFU} / \mathrm{mL}$ in stationary phase (48.45\%). Antibiotic production and activity of regenerated protoplasts were observed in all phases, except in the lag phase. The protoplast formation and regeneration techniques resulted in a new isolate strain of Streptomyces clavuligerus that produced approximately 2.5 fold more clavulanic acid.
\end{abstract}

Key words: Streptomyces clavuligerus, protoplast, clavulanic acid

\section{INTRODUCTION}

Streptomyces clavuligerus belongs to a small group of Actinomycetes characterized by beta-lactam antibiotic production and other metabolic intermediates of the biosynthetic pathways $(1,2,3,9,10,16,26)$. Isolated samples of $S$. clavuligerus, which produce at least five antibiotics, including the clavulanic acid has been described by Higgens and Kastner (12). Sermonti and Spada-Sermonti (29) were the first to report about recombination studies on Streptomyces using S. coelicolor. The protoplast fusion, transformation and improved fermentation features can be used to regenerate strains with increased antibiotic activity $(13,15,16,17)$. The protoplast formation and regeneration are important processes, and they are a major step following genetic manipulations such as fusion and DNA-mediated transformation, which can improve antibiotic production $(14,15,21,22,25)$. The initial procedures of genetic manipulation using Streptomycetes were described by
Baltz, (4,5) and Okanish et al. (28). However, reports of studies on the regeneration of protoplasts from Streptomyces are limited $(13,16)$. This paper reports the conditions for protoplast formation and regeneration from $S$. clavuligerus and also relates the improving conditions for clavulanic acid production.

\section{MATERIALS AND METHODS}

Microorganisms: Streptomyces clavuligerus NRRL 3585 (ATCC 27064), a clavulanic acid producer strain and Klebsiella pneumoniae (ATCC 29665) a clavulanic acid sensitive strain were used in this work.

\section{Experimental procedures}

Inoculum Preparation: Streptomyces clavuligerus was maintained on ISP2 medium modified by the absence of glucose (yeast extract $0.4 \%$; malt extract $1 \%$; agar $2 \%, \mathrm{pH} 7,0$ ), at $28^{\circ} \mathrm{C}$, during 10 days. Spores from a slope were inoculated in $125 \mathrm{ml}$

\footnotetext{
* Corresponding author. Mailing address: Núcleo de Pesquisas em Ciências Ambientais-UNICAP. Rua Nunes Machado, 42. Boa Vista. 50050-590, Recife, PE, Brasil. Tel.: (+5581) 3216-4001. Fax: (+5581) 3216-4004. E-mail: takaki@unicap.br
} 
Erlenmeyer flasks containing $25 \mathrm{ml}$ of fermentation medium (FM) (2), modified in the phosphate concentration to $0.435 \%$. Growth was maintained for $24 \mathrm{~h}$ in orbital shaker at $28^{\circ} \mathrm{C}$ and $200 \mathrm{rpm}$, and was used as inoculum for subsequent experiments.

Clavulanic Acid Production: For the clavulanic acid production was used FM medium and initial inoculum $\mathrm{OD}_{600}$ of 0.1 , in orbital shaker at $28^{\circ} \mathrm{C}$ and $200 \mathrm{rpm}$, during $96 \mathrm{~h}$.

Protoplasts Formation and Regeneration: Cultures described above (preculture) were used to inoculate experimental cultures consisting of 180mL GFM medium (FM medium containing $0.5 \%$ glycine) in $1000 \mathrm{~mL}$ Erlenmeyer flasks to give an initial OD of 0.1 at $600 \mathrm{~nm}$. Cultures were incubated in an orbital shaker at $28^{\circ} \mathrm{C}$ and $200 \mathrm{rpm}$ for $96 \mathrm{~h}$. Samples were collected at intervals of $24 \mathrm{~h}$, and centrifuged at 2000x $\mathrm{g}$ for 10 minutes at $28^{\circ} \mathrm{C}$. The pellets were washed with $20 \%$ (w/v) sorbitol solution, and resuspended in $5 \mathrm{ml}$ of medium for protoplast formation (MPF) containing lysozyme (EC-3.2.1.17) $1 \mathrm{mg} / \mathrm{mL}$ (16), modified by the use of sorbitol and TES (n-tris hydroximethyl-2-aminoethan sulphonic) in substitution of sucrose and MOPS (morpholino sulphonic), sterilized by membrane filtration. The samples were incubated at $28^{\circ} \mathrm{C}$ for 90 minutes, filtered through glass wool, washed with $5 \mathrm{ml}$ of MPF medium and centrifuged at $1000 \mathrm{xg}$ for 5 minutes at $28^{\circ} \mathrm{C}$. Protoplast formation was accompanied by optical and electron transmission microscopy using the method of Campos-Takaki et al. (8). To observe the protoplast regeneration, plates containing $10 \mathrm{ml}$ of regeneration medium-RM (2), modified by the absence of MOPS, were inoculated with 0.2 and $0.5 \mathrm{~mL}$ of the protoplast suspension, and $5 \mathrm{~mL}$ of regeneration medium$\mathrm{RM}$ were over laid. The Petri dishes were incubated at $28^{\circ} \mathrm{C}$ for 5 days. The control of culture was obtained with cells grown in FM medium added of $1.5 \%$ agar. The colonies formation was used to estimate the regeneration rate.

Antibiotic Activity: Ten samples with higher antibiotic activity by diffusion disc method $(11,23)$ have been selected for studies of the clavulanic acid production on FM and GFM media. The antibiotic activity was measured by the formation of an inhibition halo during 24, 48, 72 and 96h. The samples were designated in the following format: $T_{n-m}$ where $n=$ culture growth time $(1=24 ; 2=48 ; 3=72$ and $4=96 \mathrm{~h})$ and $\mathrm{m}=$ number of selected samples. Clavulanic acid production was expressed as $g$ of antibiotic per $g$ of biomass, using clavulanic acid as standard.

Analytical Methods: Biomass was determined by measurement of dry weight and related to optical density measurements at $600 \mathrm{~nm}$ using a calibration curve. Total proteins were determined by Bradford assay (7), and glycerol by enzymatic method (6).

\section{RESULTS AND DISCUSSION}

\section{Effect of growth phase on formation and regeneration of $S$. clavuligerus protoplasts}

To determine the optimal conditions for S. clavuligerus protoplasts formation, the kinetic of growth and clavulanic acid production in FM and GFM media were investigated. The culture showed a $\mu_{\max }$ of $0.04 \mathrm{~h}^{-1}$ and generation time of $17.32 \mathrm{~h}$. The glycerol consumption was proportional to biomass concentration, and exhibited a $\mathrm{V}_{\max }$ for consumption of $0.033 \mathrm{~h}^{-1}$. A growth limitation was observed after $60 \mathrm{~h}$ of fermentation, followed by glycerol exhaustion (Fig. 1A). The growth of $S$. clavuligerus in GFM medium exhibited a $\mu_{\max }$ of $0.033 \mathrm{~h}^{-1}$ and generation time of $21 \mathrm{~h}$. The $\mathrm{V}_{\max }$ of glycerol consumption was $0.066 \mathrm{~h}^{-1}$. After total glycerol consumption the cells continued to grow for $12 \mathrm{~h}$ and reached the stationary phase (Fig. 1B). The difference in antibiotic production per gram of glycerol consumed and per gram of biomass, in the two media was not significant (Table 1). However, the yield of antibiotic production per gram of extracellular protein was higher (1.655) in FM medium than in GFM medium (1.185) (Table 1). The influence of protoplasting in $S$. clavuligerus was related to mycelium age. The regeneration of cell wall occurred in crescent percentual and proportional to mycelium age fermentation. The percentage of regeneration was

Table 1. Kinetic of antibiotic activity of Streptomyces clavuligerus (wild strain) related to cellular growth in fermentation (FM) and fragilization (GFM) media.

\begin{tabular}{lcc}
\hline \multicolumn{1}{c}{$\begin{array}{c}\text { Kinetic } \\
\text { Parameters }\end{array}$} & $\begin{array}{c}\text { Fermentation } \\
\text { Medium } \\
\text { (FM) }\end{array}$ & $\begin{array}{c}\text { Fragilization } \\
\text { Medium }\end{array}$ \\
\hline g Antibiotic / g glycerol consumed
\end{tabular}

Table 2. Total number of protoplats formed from cells of Streptomyces clavuligerus and regenerate colonies, and percentage of reversion of protoplast formed during the growth.

\section{Not}

Time of Protoplasts Regenerated Regenerated Reversion Growth Formed Protoplasts Protoplasts Percentage

\begin{tabular}{ccccc} 
(h) & Cells $/ \mathrm{mL}$ & Cells $/ \mathrm{mL}$ & CFU/mL & $(\%)$ \\
\hline 24 & $5.8 \times 10^{3}$ & $4.1 \times 10^{3}$ & $1.7 \times 10^{3}$ & 28.97 \\
48 & $1.2 \times 10^{2}$ & $0.8 \times 10^{2}$ & $0.4 \times 10^{2}$ & 31.67 \\
72 & $5.4 \times 10^{3}$ & $2.9 \times 10^{3}$ & $2.5 \times 10^{3}$ & 46.30 \\
96 & $2.1 \times 10^{5}$ & $1.1 \times 10^{5}$ & $1.0 \times 10^{5}$ & 48.45 \\
\hline
\end{tabular}

$\mathrm{CFU}=$ Colonies Forming Units. 

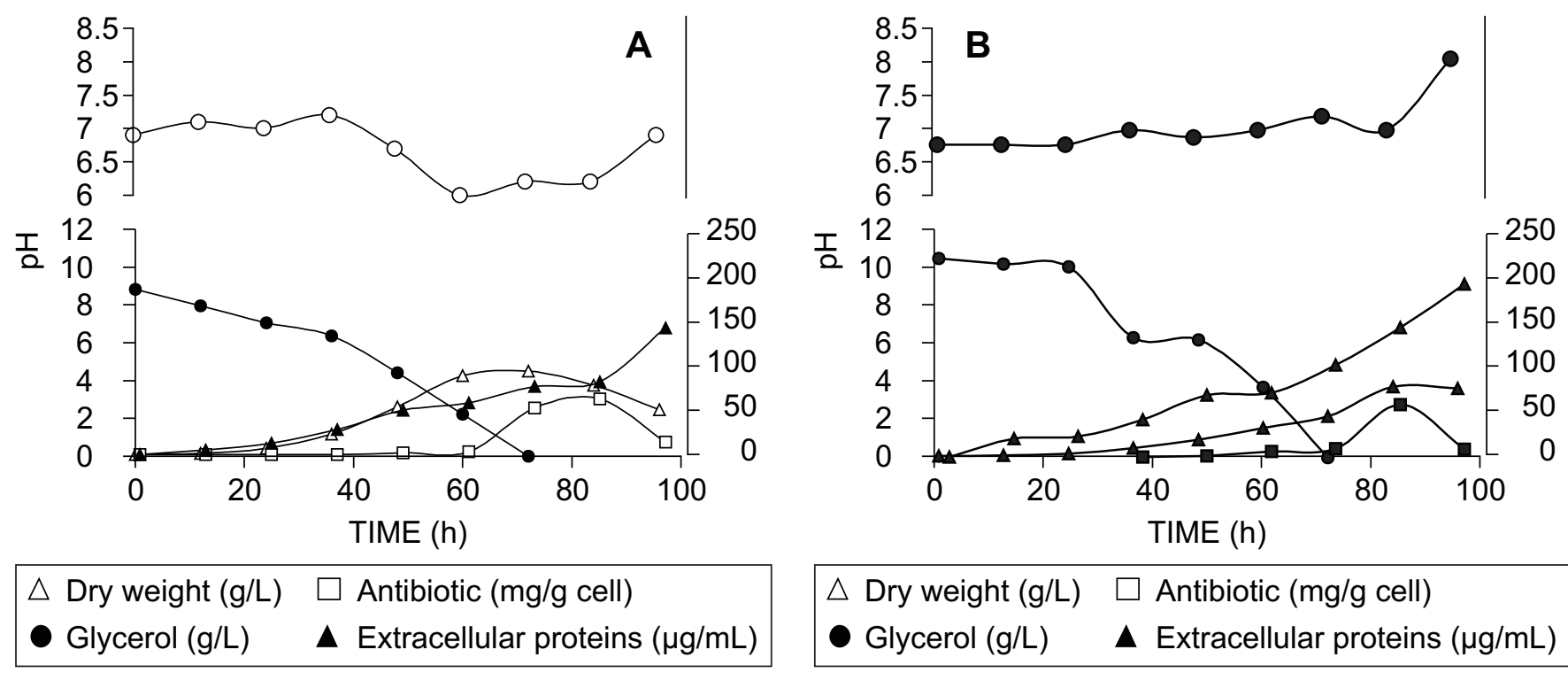

Figure 1. Growth curves, consumption of glycerol, antibiotic production, extracellular proteins and pH curves of Streptomyces clavuligerus cultures. A - Culture in FM medium. B - Culture in GFM medium.

higher in the late log phase and in the stationary phase of mycelium growth, where $46.30 \%$ and $48.45 \%$ reversion percentages were obtained, respectively (Table 2). The protocol used indicates that the age is the most important parameter for formation and regeneration protoplasts frequency. These results are supported by the literature $(16,18,20,24)$. Fig. 2 shows the sequential steps of protoplast formation from $S$. clavuligerus, revealed by transmission electron micrography. The optical microscopy of protoplasts regeneration shows presence of "coccus-like" formations, when compared with the wild sample, and consequent recuperation of the original form of the mycelium (Fig. 3). This phenomenon was also observed by Okanish et al. (28).

\section{Effect of protoplasting on antibiotic production by S. clavuligerus}

Antibiotic activity was studied with forty regenerated colonies of S. clavuligerus, using the disc diffusion method $(11,23)$. Ten selected regenerated colonies from each time interval $(24,48,72$ and 96h) were grown in fermentation medium and the antibiotic activity to clavulanic acid production was determined. The highest antibiotic activity/clavulanic acid production was observed in five strains: $\mathrm{T}_{2-1}$ and $\mathrm{T}_{2-8}(48 \mathrm{~h}) ; \mathrm{T}_{3-5}$ and $\mathrm{T}_{3-7}(72 \mathrm{~h})$ and $\mathrm{T}_{4-8}(96 \mathrm{~h})$. Antibiotic activity/clavulanic acid production was not observed in $T_{1}(24 \mathrm{~h})$. The yield of the antibiotic in regenerated samples is shown in Table 3. The antibiotic activity and the clavulanic acid production yield for antibiotic per $\mathrm{g}$ biomass obtained for $\mathrm{T}_{4-8}$ regenerated sample, showed to be about 2.5 times higher than for the wild strain. These results corroborated those by Ivanova et $a l .(19)$, who reported the influence of protoplasting and protoplast

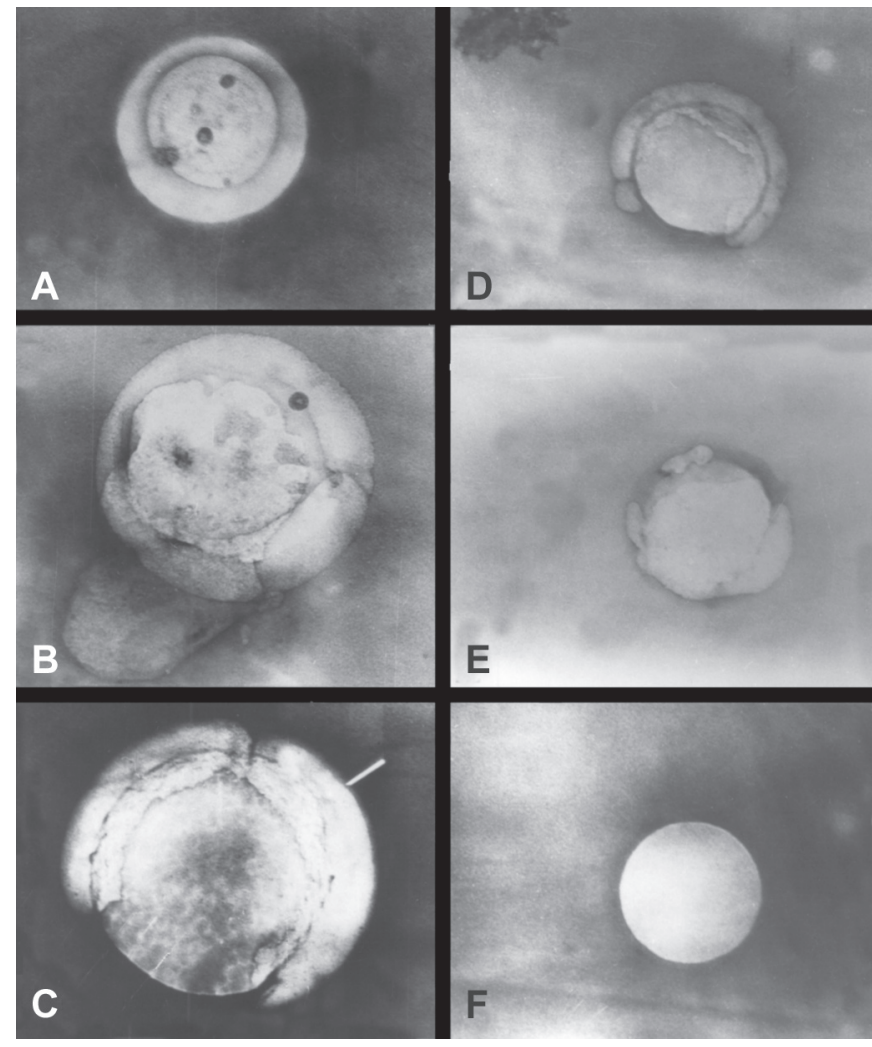

Figure 2. Transmission electron micrographs of protoplasts formation from Streptomyces clavuligerus. A - Intact cell (17000 X); B - Cell in initial process of enzymatic digestion (18000 X); C, D and E - Partially enzyme-digested cell (14400 X, 17000 X and $17000 \mathrm{X}$, respectively); F - Protoplast (17000 X). 


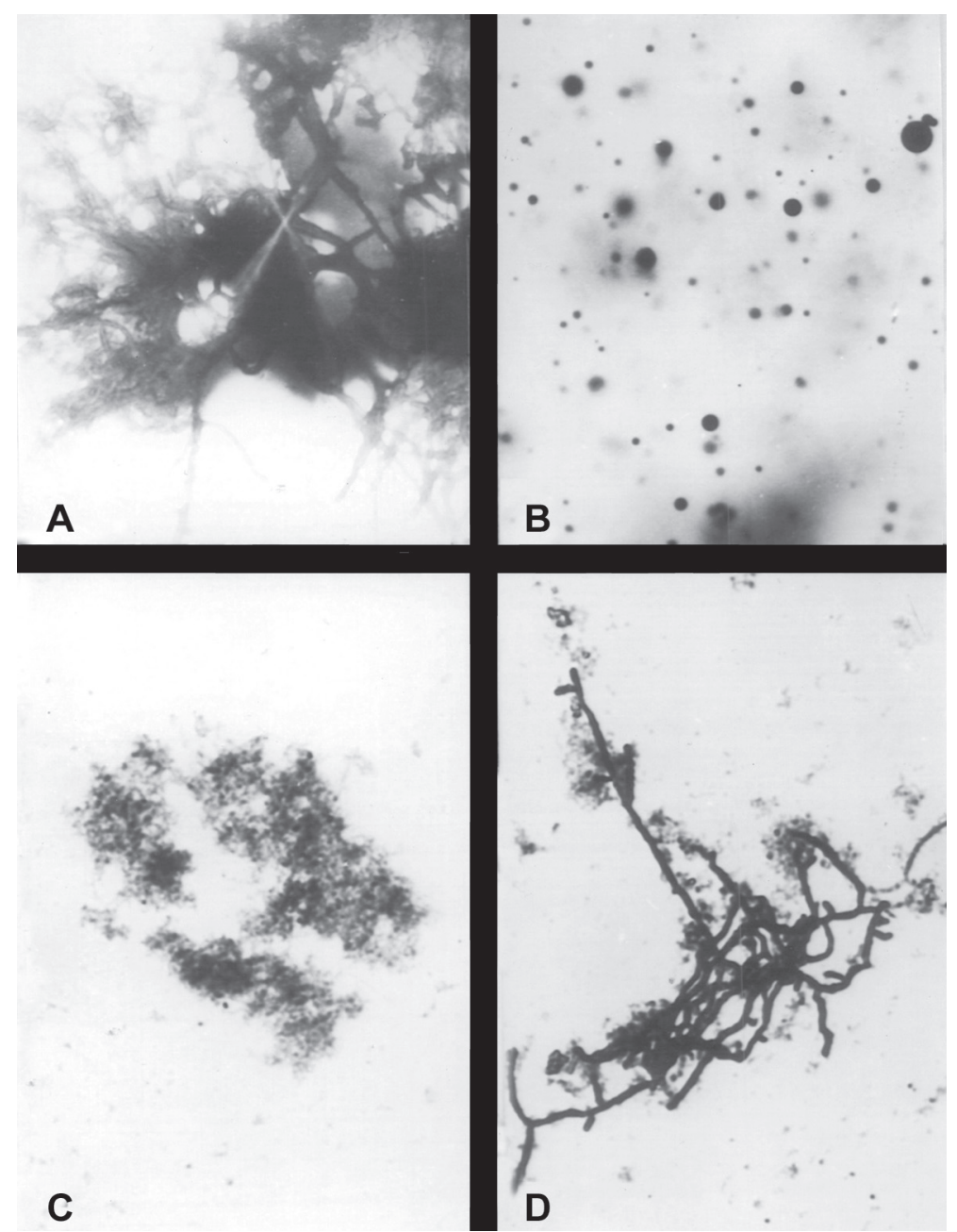

Figure 3. Optical microscopy of protoplasts formation and regeneration from Streptomyces clavuligerus. A - Wild strain (FM medium); B Protoplasts (GMF medium); C and D - Regenerated sample after growth in FM medium for 24h and 48h, respectively (250 X).

Table 3. Clavulanic acid production $(\mathrm{g})$ by biomass $(\mathrm{g})$ of Streptomyces clavuligerus wild strain and regenerated cells grown in fermentation (FM) and fragilization (GFM) media.

\begin{tabular}{ccc}
\hline \multirow{2}{*}{ Samples } & \multicolumn{2}{c}{$\begin{array}{c}\text { Clavulanic Acid Production (g) } \\
\text { Biomass (g) }\end{array}$} \\
\cline { 2 - 3 } & $\begin{array}{c}\text { Fermentation } \\
\text { Medium (FM) }\end{array}$ & $\begin{array}{c}\text { Fragilization } \\
\text { Medium (GFM) }\end{array}$ \\
\hline $\mathrm{T}_{2-1}$ & 0.050 & 0.042 \\
$\mathrm{~T}_{2-8}$ & 0.031 & 0.033 \\
$\mathrm{~T}_{3-5}$ & 0.059 & 0.059 \\
$\mathrm{~T}_{3-7}$ & $\mathrm{NS}$ & $\mathrm{NS}$ \\
$\mathrm{T}_{4-8}$ & 0.140 & 0.154 \\
Wild strain & 0.052 & 0.062 \\
\hline
\end{tabular}

NS = not significative. regeneration on the antibiotic activity. We consider that medium composition and presence of stabilizers influenced protoplast formation and regeneration, but the growth phase is the most important parameter on the process of protoplast regeneration. These results showed an enhanced antibiotic activity, with beneficial effects on clavulanic acid production by the use of an effective protoplasts-regeneration system.

\section{ACKNOWLEDGMENTS}

The authors are grateful to JICA, FINEP and CNPq.

\section{RESUMO}

\section{Formação e regeneração de protoplastos de Streptomyces clavuligerus NRRL 3585 e produção de ácido clavulânico}

Protoplastos foram formados a partir de esporos da amostra selvagem de Streptomyces clavuligerus durante a fase lag, exponencial e estacionária de crescimento, utilizando glicina a $0.5 \%$ como meio de cultura. Os protoplastos foram obtidos pelo tratamento das células com lisozima (EC-3.2.1.17) $40.000 \mathrm{U}(1 \mathrm{mg} / \mathrm{mL})$ em solução osmótica de sorbitol e TES, por $90 \mathrm{~min}$ a $28^{\circ} \mathrm{C}$. A frequiência de protoplastos regenerados na fase lag foi de $1,7 \times 10^{3} \mathrm{UFC} / \mathrm{mL}$ $(28,97 \%)$, no início da fase exponencial correspondeu a $0,4 \times 10^{2} \mathrm{UFC} / \mathrm{mL}(31,67 \%)$, no final da fase exponencial observou-se $2,5 \times 10^{3} \mathrm{UFC} / \mathrm{mL}(46,30 \%) \mathrm{e}$ para a fase estacionária de crescimento apresentou $1,0 \times 10^{5} \mathrm{UFC} / \mathrm{mL}(48,45 \%)$. A produção do antibiótico e a atividade antibiótica dos protoplastos regenerados foram observadas em todas as fases de crescimento, exceto na fase lag. As técnicas de formação de protoplastos e regeneração resultaram em uma nova linhagem de Streptomyces clavuligerus produzindo 2,5 vezes mais ácido clavulânico.

Palavras-chave: Streptomyces clavuligerus, protoplasto, ácido clavulânico.

\section{REFERENCES}

1. Aharonowitz, Y.; Friedrich, C.G. Alanine dehydrogenase of the betalatcam antibiotic producer Streptomyces clavuligerus. Arch. Microbiol., 125: 137-142, 1980.

2. Aharonowitz, Y.; Demain, A.L. Carbon catabolite regulation of cephalosporin production in Streptomyces clavuligerus. Antimicrob. Agents Chemother, 14: 159-164, 1978.

3. Bachmann, B.O.; Towsend, C.A. Kinetic mechanism of the betalactam synthetase of Streptomyces clavuligerus. Biochemistry, 39(37): 11187-11193, 2000. 
4. Baltz, R.H. Genetic recombination in Streptomyces fradiae by protoplast fusion and cell regeneration. J. Gen. Microbiol., 107: 93102,1978

5. Baltz, R.H.; Matsushima, P. Protoplast fusion in Streptomyces: conditions for efficient genetic recombination and cell regeneration. J. Gen. Microbiol., 127: 137-146, 1981

6. Boehringer Mannheim. Glycerol. In: Methods of enzymatic food analysis. Mannhein: 1984, p.33-34.

7. Bradford, M.M. A rapid and sensitive method for the quantitation of microgram quantities of protein utilizing the principle of proteindye binding. Anal. Biochem., 72: 248-254, 1976.

8. Campos-Takaki, G.M.; Beakes, G.W.; Dietrich, S.M.C. Electron microscopie X-ray microprobe and cytochemical study of isolated cell walls of Mucoralean fungi. Trans. British Mycol. Soc., 80: 536$541,1983$.

9. Elson, S.W. The biosynthesis of clavulanic acid and related metabolism of Streptomyces clavuligerus. R. Soc. Chem., 38: 143150,1981

10. Elson, S.W. Studies on the biosynthesis of clavulanic acid. Incorporation of ${ }^{13} \mathrm{C}$-labelled precursors. Antib., 31: 586-592, 1978.

11. Ericsson, H.M.; Sherris, J.C. Antibiotic sensitivy testing - report of an international collaborative study. Acta Pathol. Microbiol. Scand., 217: 1-90, 1971 .

12. Higgens, C.E.; Kastner, R.E. Streptomyces clavuligerus sp.nov., a beta-lactam antibiotic producer. Int. J. Syst. Bacteriol., 21: 326-331, 1971.

13. Hopwood, D.A. Genetic studies with bacterial protoplasts. Ann. Rev. Microbiol., 35: 237-272, 1981.

14. Hopwood, D.A.; Bibb, M.J.; Chater, K.F., et al. Genetic manipulations of Streptomyces; a laboratory manual. Normichi: Crowe and Sous, 1985, p.356.

15. Hui, Z.; Shinakawa, H.; Ishikawa, J.; Kinashi, H.; Nimi, O. Improvement of transformation system in Streptomyces using a modified medium. J. Ferment. Bioengin., 83(3): 217-221, 1997.

16. Illing, G.T.; Normansell, I.D.; Peberdy, J.F. Protoplast isolation and regeneration in Streptomyces clavuligerus. J. Gen. Microbiol., 135: 2289-2297, 1989a.
17. Illing, G.T.; Normansell, I.D.; Peberdy, J.F. Genetic mapping in Streptomyces clavuligerus by protoplast fusion. J. Gen. Microbiol., 135: 2299-2305, 1989b.

18. Iralulin, V.P.; Podgornnova, G.P.; Strulina, E.A.; Rumiantseva, V.Iu.; Danilenko, V.N. Preparation and chateristics of protoplasts of Streptomyces kanamyceticus. Antib. Chemoth., 35(6): 3-6, 1990.

19. Ivanova, I.V.; Khristova, K.G.; Tishkov, S.Kh.; Moncheva, P.A. Effect of protoplasting on antibiotic activity and resistance in the strain Streptomyces hygroscopicus 155. Antib. Chemoth., 37(11): 3-5, 1992.

20. Khristova, K.R.; Petkova, V.T.; Danilenko, V.N.; Ivanova, I.V.; Bakalov, B.V. Preparation and regeneration of the strain Srteptomyces hygroscopicus 155. Antib. Chemoth., 037(12): 2426, 1992.

21. Kirby, R. An unstable genetic element affecting the production of the antibiotic holomycin by Streptomyces clavuligerus. FEMS Microbiol. Letters, 3: 283-286, 1978.

22. Liras, P.; Rodriguez-Garcia, A. (2000), Clavulanic acid, a betalactamase inhibitor: biosynthesis and molecular genetics. Appl. Microbiol., 4: 467-475, 2000.

23. Lorian, V. Disk susceptibility test. In: Antibiotics in laboratory medicine. William \& Wilkins, Baltimore, 1986, 27-60p.

24. Lyutzkanova, D.; Nikolova, B.; Stoilova-Discheva, M.; Todorov, T. Protoplast formation and regeneration in Streptomyces flavopersicus. Lett. Appl. Microbiol., 16(4): 217-219, 1993.

25. Martin, J.F. New aspects of genes and enzymes for beta-lactam antibiotic biosynthesis. Appl. Microbiol. Biotechnol., 50: 1-15, 1998.

26. Mayer, A.F. and Deckwer Simultaneous production and decomposition of clavulanic acid during Streptomyces clavuligerus cultivations. Appl. Microbiol. Biotechnol., 45: 41-46, 1996.

27. Ochi, K.; Hitchock, M.J.M.; Katz, E. High-frequency fusion of Streptomyces parvulus on Streptomyces antibiotics protoplasts induced by polyethylene glycol. J. Bacteriol., 139: 984-992, 1979.

28. Okanish, M.; Suzuki, K.; Umezawa, H. Formation and reversion of streptomycete protoplasts cultural condition and morphological study. J. Gen. Microbiol., 80: 389-400, 1974.

29. Sermonti, G.; Spada-Sermonti, I. Genetic recombination in Streptomyces. Nature, 23: 176-121, 1955. 